\title{
Strategies for Implementing Agro-Industrial Policy in the Face of Climate Change in South-Western Nigeria
}

\author{
Ogunwale, A. B ${ }^{1}$, Akintonde, J. $\mathbf{O}^{1}$, Amao, J. $\mathrm{O}^{2}$ \\ ${ }^{1}$ Department of Agricultural Extension and Rural Development, Ladoke Akintola University of Technology, \\ P.M.B. 4000, Ogbomoso, Nigeria \\ ${ }^{2}$ Department of Agricultural Economics, Ladoke Akintola University of Technology, P.M.B. 4000, Ogbomoso, \\ Nigeria \\ Corresponding Author: Ogunwale, A. B
}

\begin{abstract}
The development of the agro-industrial sector lies in increasing agricultural productivity which is directly affected by climatic changes. The study, therefore, evaluated the strategies for implementing agro-industrial policy in the face of climate change in Southwestern, Nigeria. The study adopted a participatory Field Survey Method to carry out a preliminary survey, while a multistage sampling procedure was used to select 238 crop processors/agro-industrialist. Data were collected through a structured interview schedule and analyzed with frequency distribution and percentage as main descriptive statistical tools. The study revealed different subsectors of agriculture adversely affected by climate change and several recommendations for policy formulation on climate change for sustainable agro-industrialization in the area. The study, therefore, recommends that stakeholders in agro-processing industries and governments at various levels should engage in regular consultation and participatory management mechanisms to reduce the effects of climate change on agro-industries and come up with policy documents that will promote and enhance sustainable agro-industrialization in South-west in particular and Nigeria at large.
\end{abstract}

Key Words: Agro-Industries, Agro-processors, Climate Change, Policy Issues

\section{INTRODUCTION}

Nigeria is still grappling with fundamental issues of food security and sustainable agriculture on a landmass that is about $80 \%$ arable is indefensible. According to the Federal Ministry of Agriculture and Water Resources ${ }^{[2]}$, crop production alone contributes $85 \%$ to Nigeria's agricultural Gross Domestic Product (GDP). More than $90 \%$ of agricultural output is accounted for by smallholder farmers with less than two hectares under cropping. Over the years, Nigeria has devoted large hectares of land to the cultivation of arable crops, however, production has remained low, a phenomenon that has entangled the farmers in a vicious circle of poverty. The World Bank ${ }^{[13]}$ recommended some measures to improve agriculture and to enhance the prospects of agribusiness and agro-industrial sub-sector as an avenue for self-employed private enterprise creation. These measures include access to agricultural and agroenterprise finance, measures of policy certainty, and the orientation of the enabling environment as perceived by the private sector and various policy, trade and fiscal measures ${ }^{[4]}$.

Agro-processing industries are major sources of employment and income, and they provide access to food and other necessities to large groups of the population. The kinds of Agro-processing industries to steer the agro-industrial development towards the path of sustainable agricultural 
development in Nigeria are many. These include the following among others;

(i) Food and fruit juice canners

(ii) Manufacturers of soft drinks and cocoa drinks, cashew juice drinks.

(iii)Producers of confectionary sugar-sweet, cassava cakes, biscuits

(iv)Wood processors and furniture makers and distributors,

(v) Paper millers and tissue paper manufacturers

(vi)Cassava cottage factory for processing cassava into "gari" "lafun", "fufu", tapioca and chips

(vii) Yam flakes and flour processors.

(viii) Food processors of cornflakes, jam, bread, milk, yoghurt, margarine and tomato puree.

(ix)Palm and groundnut oils, soap, detergent maters

(x) Fishing companies, fish drying, fish processors, packers and distributors

The potential for agro-industrial development in South-west Nigeria is largely linked to the conducive climatic condition for various agricultural raw materials. Agro-industrial development is capable of generating higher incomes, and these new income levels are capable of empowering small-holder farmers into medium to large holders, thereby reducing the poverty level among small-holder farmers. Therefore, efforts should be made to enhance the value chain process in agriculture via employment generation, income generation, opening market opportunities for agricultural produce and poverty reduction through sustainable agroindustrial development to ensure growth and development of rural communities in the South-West Nigeria. The climate is crucial to the Nigerian agribusiness value chain ${ }^{[10]}$. If action is not taken, the impact of the change on weather will continue to cause severe effects on livelihoods in Nigeria. The Nigerian range of climate variations gives it an edge to be able to produce different kinds of crops ranging from food crops to cash crops ${ }^{[1]}$. According to Intergovernmental Panel on Climate Change ${ }^{[8]}$, the human influence on the change in climate conditions is real, and the most common activity is the anthropogenic greenhouse gas emissions. National Aeronautics and Space Administration (NASA) ${ }^{[9]}$ argued that the global climate is changing faster than at any time in the history of modern civilization because of human activities.

Again, ${ }^{[8]}$, explained that climate change is real, and it will always be tough to understand a complicated system like the global climate. However, there is evidence in Nigerian agribusiness value chain that the climate is changing and global warming is happening. The effects of climate change are expected to be severe on those business and industries whose major inputs lies in agriculture. Nigeria has taken the challenge of climate change seriously. The First National Communication was produced in November 2003. A stakeholders' initiation workshop on the Second National Communication (SNC) took place in December 2009 and is being finalized and a National Adaptation Strategy and Action Plan (NASPA) has been concluded. Nigeria now has a Climate Change Department (CCD) in the Federal Ministry of Environment in Abuja, Nigeria. The CCD was created to implement the Climate Convention and protocol activities. It also coordinates the activities of the Interministerial Committee on Climate Change [3].

Nigeria already has several policies and strategic initiatives which if properly implemented, can serve as adaptive as well as mitigative climate change measures. Many of the initiatives in these policies (e.g. oases rehabilitation in the National Action to Combat Desertification and the National Policy on Drought and Desertification) can be taken as anticipatory adaptation measures and plans, which can be fine-tuned into policy options for climate change response in the country ${ }^{[3]}$. This comprehensive policy and response strategy will enable these policies to translate into meaningful inter-sectoral activities for sustainable environmental management and industrial 
development. It is on the above premise, this study was embarked upon to evaluate the strategies for implementing agroindustrial policies in the face of climate change in Southwestern, Nigeria. Specifically, the study described the socioeconomic characteristics of the respondents in the region; identified subsectors of agriculture adversely affected by climate change, and proffer a comprehensive set of recommendations as policy measures to enhance sustainable agro-industrial development in the area.

\section{CONCEPTUAL FRAMEWORK}

Nigeria recognizes climate change as a strategic priority. It has adopted Nigeria climate change policy responses and strategies. There is a national Adaptation Strategy and Plan to Action on climate change the ministry of Environment has a dedicated Department of climate change and there are plans for a climate change trust fund. Therefore, Nigeria has several climate change policies and plans but still doesn't have a climate change Act or Bill to guide climate actions in the country on agroindustrial development. Hence, there is a need to review Nigeria climate change policy to enhance sustainable agro-industrial development in the country.

The supply of raw materials to the agro-industrial processing and manufacturing sector is a primary role of agriculture. This role also facilitates the other traditional roles of agriculture as a food supplier, provider of employment opportunities, and income generation and source of foreign exchange earnings through exports. Therefore, the negative impact of climate change-related disasters can pose very serious challenges for the government development agenda. Such disasters can hinder economic growth, slow the pace of human development, reduce agricultural production, cause sharp increases in poverty, lower the rate of agro-industrial development, and hurt the poor in the short run while reducing their chances of escaping poverty in the long run. Climate change- related disasters, therefore, can potentially cause deviations from sustainable development paths depending on their magnitude.

Global Climate Change is a threat that is already having initial tangible impacts upon humans, land, and nature today. German Advisory Council on Global Change report ${ }^{[5]}$ shows that the USA and Europe account for more than half of Global Greenhouses Gas (GHG) emissions, SubSahara, $1.59 \%$ and the small island States $0.37 \%{ }^{[12]}$. Unfortunately, the impacts of climate change on livelihoods and agriculture in countries of the South-Sahara (including Nigeria) are inversely proportional to the nations' responsibility for the problem. This is because the countries that significantly contribute to climate change do not suffer much from its effects as developing countries Nigeria inclusive, because of their natural advantage, institutional capacities, wealth statuses, high adaptation strategies, high technologies, and stable polity ${ }^{[5]}$.

In developing countries like Nigeria, the increase in drought, soil degradation and growing water scarcity in combination with high population growth, unstable institutions, poverty or a high level of dependency on agriculture means that there is a particularly significant risk of environmental migration occurring and increasing in scale ${ }^{[7]}$. This will adversely affect agro-industrial development. For this reason, all sectoral policies must contain and address climate change issues relating to each other.

\section{METHODOLOGY}

The study was carried out in the southwestern zone of Nigeria. It is a Yoruba region, land and Yoruba speaking area, with different dialects even within the same state. The weather conditions vary between the two distinct seasons in Nigeria; the rainy season (March - November) and the dry season (November - February). The dry season is also the bringer of the Harmattan dust; cold dry winds from the northern 
Ogunwale, A.B et.al. Strategies for implementing agro-industrial policy in the face of climate change in SouthWestern Nigeria.

deserts blow into the southern regions around this time (www.myguidenigeria.com). The study adopted Participatory Field Survey Method (PFSM) to carry out a preliminary survey of the study area, and to identify the study respondents. The study respondents comprise the crop processors and agroindustrialists involved in cottage industries such as cassava, yam, oil palm maize, groundnuts and other small-scale processing enterprises. A multi-stage sampling technique was used to select Local Government Areas from which agroprocessors and agro-industrialists were randomly selected for data collection. Purposive sampling technique was used to select rural-based Local Government Areas in the five states of the South-west zone of Nigeria. Lagos State was excepted while Oyo, Osun, Ogun, and Ekiti were included in the study. The purposive sampling technique was used to select rural cropprocessors and agro-industrialists who were actively engaged in crop processing and agro-industries at the time of data collection. In Oyo, Osun, Ondo and Ekiti states, 50 respondents each were purposively selected while 38 respondents were selected in Ogun State. Therefore, two hundred and thirty-eight (238) constituted the sample size of the study. A structured interview schedule was used to collect relevant data from selected crop-processors and agro-industrialists. Relevant secondary data were collected through a desk review of relevant literature on climate change.

Data were collected on, socioeconomic characteristics of crop-processors and agro-industrialists; subsectors of agriculture adversely by climate change; and recommendations for policy formulation on climate change. This is an empirical study that used both qualitative and quantitative data. Descriptive statistics tools such as Tables, frequency distribution and percentages were employed in data analysis.

\section{RESULTS AND DISCUSSION Socio-economic characteristics of selected Agro-processors}

Table 1 reveals the socio-economic characteristics of the agro-processors included in the study. The majority (65.5\%) of the agro-processors were male while $34.0 \% \%$ were female. This shows that both males and females were involved in agroprocessing activities in Southwest, Nigeria. However, male agro-processors were dominant in the subsector. It was also revealed that about $81.5 \%$ of the agroprocessors were between the ages of 30 and 59 years. This shows that they are very active, agile and mature to face the challenges and rigour involved in agroprocessing activities such as transporting raw materials, processing, packaging and marketing. The data in Table 1 further reveals that about $82.2 \%$ of the agroprocessors were literate with abilities to read and write. They possessed West African Examination Council (WAEC), Senior Secondary School Certificate (SSCE), National Certificate in Education (NCE), Ordinary National Diploma (OND), Higher National Diploma (HND) and B.sc Degree Certificates. This suggests that they should be capable of running their agro-business ventures and processing activities with knowledge and acquired skills to improve their productivity and income. This implies that efforts can be made to build their capacities to manage agro-allied ventures and to encourage them to expand their scale of operations and employ more labourers in their businesses.

Table1 also reveals that the majority of the agro-processors had been involved in agro-processing and agro-business activities for more than five years as at the time of the study. About $87.0 \%$ of the agro-processors had between 5 and 30 years of experience in agro-based enterprises. This shows that their practical experiences in the sub-sector can be tapped to develop well-articulated and robust policies for agro-industrial development in Southwest, Nigeria. In terms of the scale of operation, it was 
Ogunwale, A.B et.al. Strategies for implementing agro-industrial policy in the face of climate change in SouthWestern Nigeria.

revealed that the majority of the agroprocessors $(80.7 \%)$ were operating on a small scale, while $17.6 \%$ and $1.7 \%$ were on medium-scale and large-scale operations respectively. It shows that agro-based enterprises need to be stepped up to increase their scale of operations to generate more employment opportunities for Nigeria youth, and improve the contribution of small- medium-large scale enterprises to the Gross Domestic Products (GDP) and national economic development.

The Table further shows that the majority of agro-processors (68.9\%) secured their raw materials majorly from contractors/suppliers while $21.8 \%$ agroProcessor secured their raw materials from the open market. Only $7.6 \%$ of the sampled agro-processors secured their raw materials from their farms. This shows that the processing activities of the agro-processors will be determined by the availability of raw materials as at when due and this will eventually determine the continuous operations of the agro-processors. This implies that the profitability of agroventures will be largely determined by the cost of raw materials from other sources and transaction costs associated with raw material procurement.

The agro-processors were asked about their level of awareness of climate change as it affected their activities. $85.7 \%$ of agro-processors confirmed their awareness of climate change while only $14.3 \%$ said they did not aware. This shows that there is increasing awareness of the local manifestations of the global problem of climate change, hence it will be easier to develop community-level and policy-based climate change adaptation strategies that will engender sustained agro-industrial development.

Table 1: Distribution of Agro- Processors by their Socio-economic Characteristics $\quad$ n=238

\begin{tabular}{|c|c|c|c|}
\hline Socio-economic Characteristics & Frequency & Percentage & Cumulative Percentage \\
\hline $\begin{array}{l}\text { Sex: Male } \\
\text { Female }\end{array}$ & $\begin{array}{l}152 \\
82\end{array}$ & $\begin{array}{l}65.5 \\
34.5\end{array}$ & $\begin{array}{l}65.5 \\
100.00\end{array}$ \\
\hline $\begin{array}{l}\text { Age- group (years) } \\
20-29 \\
30-39 \\
40-49 \\
50-59 \\
60-69 \\
70 \text { and above }\end{array}$ & $\begin{array}{l}8 \\
38 \\
100 \\
56 \\
34 \\
2\end{array}$ & $\begin{array}{l}3.8 \\
16.0 \\
42.0 \\
23.5 \\
14.3 \\
0.8\end{array}$ & $\begin{array}{l}3.4 \\
19.3 \\
61.3 \\
84.9 \\
99.2 \\
100.0\end{array}$ \\
\hline $\begin{array}{l}\text { Highest Level of Education attainment } \\
\text { No formal education } \\
\text { Primary school certificate } \\
\text { Secondary school certificate WAEC/SSCE } \\
\text { Tertiary Education Certificate NCE/OND/HND/First Degree }\end{array}$ & $\begin{array}{l}8 \\
20 \\
64 \\
146\end{array}$ & $\begin{array}{l}3.4 \\
8.4 \\
26.9 \\
61.3\end{array}$ & $\begin{array}{l}3.4 \\
11.8 \\
38.7 \\
100.0\end{array}$ \\
\hline $\begin{array}{l}\text { Years of experience in agro-based enterprises } \\
\text { Less than 5years } \\
5-10 \text { years } \\
11-20 \text { years } \\
21-30 \text { years } \\
31 \text { and above years }\end{array}$ & $\begin{array}{l}24 \\
142 \\
64 \\
6 \\
2\end{array}$ & $\begin{array}{l}10.1 \\
59.6 \\
26.9 \\
2.5 \\
0.8\end{array}$ & $\begin{array}{l}10.1 \\
69.7 \\
96.6 \\
99.2 \\
100.0\end{array}$ \\
\hline $\begin{array}{l}\text { Level of operation } \\
\text { Small- Scale } \\
\text { Medium Scale } \\
\text { Large scale }\end{array}$ & $\begin{array}{l}192 \\
42 \\
4\end{array}$ & $\begin{array}{l}80.7 \\
17.6 \\
1.7\end{array}$ & $\begin{array}{l}80.7 \\
98.3 \\
100.0\end{array}$ \\
\hline $\begin{array}{l}\text { The major source of raw materials } \\
\text { Farmgate } \\
\text { Open market } \\
\text { Contractor/supplies } \\
\text { Personal farm }\end{array}$ & $\begin{array}{l}4 \\
52 \\
164 \\
18\end{array}$ & $\begin{array}{l}1.7 \\
21.8 \\
68.9 \\
7.6\end{array}$ & $\begin{array}{l}1.7 \\
23.5 \\
92.4 \\
100.0\end{array}$ \\
\hline $\begin{array}{l}\text { Awareness of climate change } \\
\text { No } \\
\text { Yes }\end{array}$ & $\begin{array}{l}34 \\
104\end{array}$ & $\begin{array}{l}14.3 \\
85.7\end{array}$ & $\begin{array}{l}14.3 \\
100.0\end{array}$ \\
\hline
\end{tabular}

Source: Field Survey, 2018

\section{Subsectors of agriculture being adversely affected by climate change in Southwest, Nigeria}

Table2 reveals different subsectors of agriculture being adversely affected by climate change. It was revealed that $78.2 \%$ 
Ogunwale, A.B et.al. Strategies for implementing agro-industrial policy in the face of climate change in SouthWestern Nigeria.

of the respondents indicated agro-processing industries; Forestry and Agroforestry products e.g. woods (73.9\%); food crops (e.g. cereals, legumes, root and tubers) production (73.9\%); industrial crop e.g. cocoa, cashew, sugarcane, oil palm, orange and mango production (58.8\%); farm produce marketing $(57.1 \%)$ and livestock (e.g. poultry, piggery and cattle) production subsectors were being adversely affected by climate change. The impacts of climate change on agriculture are projected to manifest through changes in land and water regimes, especially, changes in the frequency and intensity of droughts, flooding, water shortages, worsening soil conditions, desertification, disease and pest outbreaks on crops and livestock [8]. The Nigerian's agricultural activities are rain-fed and the farmers are engaged in crop production, livestock rearing, fisheries and post-harvest activities. Also, reductions in crop yield are imminent due to decreased water availability and changed insect pest incidence. Agriculture in the Southwest is rainfall dependent, and rain led crops yields are likely to fall sharply for even a small climate change. [11] projected a fall in agricultural productivity of up to $30 \%$ over the $21^{\text {st }}$ century.

Table2: Distribution of subsectors of agriculture being adversely affected by climate change in South West, Nigeria

\begin{tabular}{|c|c|c|c|}
\hline & Subsectors of agriculture & Frequency & Percentage \\
\hline 1. & Industrial crop e.g cocoa, cashew, sugarcane, oil palm, orange and mango production & 140 & 58.8 \\
\hline 2. & Food crops (e.g cereals, legumes, root and tubers) production & 176 & 73.9 \\
\hline 3. & Horticulture (e.g flowers and high value fruits and vegetable) production & 62 & 26.1 \\
\hline 4. & Livestock (e.g poultry, piggery and cattle) production & 102 & 51.3 \\
\hline 5. & Forestry and Agroforestry products (e.g woods) & 176 & 73.9 \\
\hline 6. & Farm produce marketing & 136 & 57.1 \\
\hline 7. & Agro-processing industries & 186 & 78.2 \\
\hline
\end{tabular}

Source: Field Survey, 2018

\section{Recommendations for policy formulation on climate change for sustainable agro- industrialization of Southwest Nigeria}

Table 3: Distribution of recommendations for policy formulation on climate change forsustainable agro-industrialization made by selected Agro-processors and Agro-industrialist in South West, Nigeria

\begin{tabular}{|c|c|c|c|}
\hline & Policy Issues & Frequency & Percentage \\
\hline i. & There is a need for the expansion of capacity through value addition & 226 & 95.0 \\
\hline ii. & The engagement of small-medium Enterprises (SME) is imperative & 224 & 94.1 \\
\hline iii. & The improvements of technical and technological capacities & 224 & 94.1 \\
\hline iv. & The reduction of cost of doing business by improving infrastructure and lowering energy cost & 214 & 89.9 \\
\hline V. & Improving access to finance especially for SME & 208 & 87.4 \\
\hline vi. & Improving institutional frameworks & 218 & 91.6 \\
\hline Vii & Capacity enhancement especially for technical skills required for agro-processing & 184 & 77.3 \\
\hline Viii & Increasing the manufacturing base to stimulate economic growth and development. & 212 & 89.1 \\
\hline $\mathrm{Ix}$ & Increasing valve addition of primary raw products for exports & 224 & 94.1 \\
\hline $\mathrm{x}$. & Improving access to financial service & 212 & 89.1 \\
\hline xi. & $\begin{array}{l}\text { Provision of Support services such as infrastructure and information and communication technology } \\
\text { (ICT) }\end{array}$ & 214 & 89.9 \\
\hline Xii & Organizing supply chains or value chains that have forward background linkages & 222 & 93.3 \\
\hline
\end{tabular}
Source- Field Survey, 2018

Table3 summarized the recommendations of selected agroprocessors for policy formulation on climate change for enhanced agro-industrialization in Southwest, Nigeria. Majority of the samples agro-processors and agroindustrialist recommended the following policy issues on climate change (i) the engagement of small medium-enterprises is imperative (94.1\%); (ii) the improvements of technical and technological capacities
(94.1\%); (iii) increasing value addition of primary raw products for export (94.1\%); (iv) organizing supply chains or value chains that have forward background linkages (93.3\%); (v) improving institutional frameworks (91.6\%) ; (vi) the reduction of cost of doing business by improving infrastructure and (vii) lowering energy cost (89.9\%); Provision of support services such as infrastructure and information and communication technology 
(ICT) (89.9\%); increasing the manufacturing base in order to stimulate economic growth and development (89.1\%); improving access to financial service (89.1\%); improving access to finance especially for SME (87.4\%) and capacity enhancement specially for technical skills required for agro- processing $(77.3 \%)$ were also recommended by the sampled crop processors and agro-industrialists.

The above findings revealed the need for governments at Federal State and Local levels to establish participatory consultancy systems for agro-processors and agro-industrialists in Southwest, Nigeria, and embark on intervention programmes through the management of policies and regulations relevant for the operation of agro-industries that can ensure sustainable livelihoods and as well help mitigate climate change impacts on agro-industries in Southwest, Nigeria.

\section{CONCLUSION AND RECOMMENDATIONS}

The study evaluated the strategies for implementing agro-industrial policy in the face of climate change in South-west, Nigeria. Information was collected from different age groups crop processors/agroindustrialists; different educational background and years of experience and operating at different scale level of production. Most of the processors and industrialists sampled are aware of climate change. Different agro-industries are adversely affected by the incidence of climate change in the region (South-west, Nigeria) The sampled crop processors and agro-industrialists recommended several policy issues that are expected to provide useful information that can serve as insights for policymakers in the developing and formulating policy concerning agroindustries and climate change. Hence, the governments at Federal State and local levels have greater responsibilities in providing policy measures that will reduce the effects of climate change on the subsectors of agriculture and most importantly agro-industries and develop specific policies for implementation to enhance sustainable agro-industrialization in South-west, Nigeria. The study, therefore, recommends that stakeholders in the agroprocessing industry and governments at various levels should engage in regular consultation and participatory management mechanisms to reduce the effects of climate change on agro-industries and come up with policy documents that will promote and enhance sustainable agro-industrialization in South-west in particular and Nigeria at large.

\section{ACKNOWLEDGEMENT}

We appreciate and sincerely acknowledge the financial support of the Tertiary Education Trust Fund (TETFUND) through Research Grant for Institutional Based research project, given to me to execute this study.

\section{Conflict of Interest: None}

\section{Source of Funding: None}

\section{REFERENCES}

1. Fakayode, S., Rahji, M.A.Y. and Adeniyi, S. (2012): "Economic Analysis of Risks in Fruit and Vegetables, "Bangladesh J. Agril. Res, vol. 37, no. September, pp. 473-491.

2. Federal Ministry of Agriculture and Water Resources (FMA\&WR 2008); National Programme for Food Security. Federal Ministry of Agriculture and Water Resources, Abuja, pp. 107.

3. FME (2020): National Policy on Climate Change. Federal Ministry of Environment, Department of Climate Change, pp. 10

4. Food and Agriculture Organization of the United Nations (FAO, 2007): Adaptation to Climate Change in Agriculture, Forestry and Fisheries Perceptive. Framework and Priorities. Rome Available at www.fao.org/icatalog/inter.e.htw)

5. German Advisory Council on Global Change (WBGU) 2003): Climate Protection Strategies for the $21^{\text {st }}$ Century. Kyoto and beyond. Special Report. Berlin Germany WBGU. 
Ogunwale, A.B et.al. Strategies for implementing agro-industrial policy in the face of climate change in SouthWestern Nigeria.

6. German Advisory Council on Global Change (WBGU) (2007): World in Transition. Climate Change as a Security Risk. Berlin, Germany, WBGU, pp.13.

7. Intergovernmental Panel on Climate Change (IPCC)(2014): Mitigation of Climate Change.

8. IPCC (2001): "The carbon cycle and atmospheric carbon dioxide," in Climate Change 2001: The Scientific Basis.

9. National Aeronautics and Space Administration (NASA) (2020):"Scientific Consensus: Earth's Climate is Warming".

10. Posthumus, H., Dengerink, J., Dhamankar, M., Plaisier, C. and Baltissen, G. (2019): "Enhancing Food Systems in Nigeria; Scope and perspective for Dutch policy interventions," Netherlands Ministry of Foreign Affairs.

11. Richards, M. (2003), Poverty Reduction, Equity and Climate Change. Global
Governance Synergies, Overseas Development Institute. Globalization and Poverty Programme.

12. Spore (2008) Climate Change. A. Bimonthly Magazine of the Technical Centre for Agriculture and Rural Cooperation (CTA), Wageningen.

13. World Bank (2012): Agribusiness Indicators in Ghana Economic and Sector Work Report Number 68163- Ghana Economic Washington, DC 20433.

14. https://www.myguidenigeria.com/regionalin fo/south-west-region. Retrieved 2020-11-20.

How to cite this article: Ogunwale, A.B, Akintonde, J.O, Amao, J.O. Strategies for implementing agro-industrial policy in the face of climate change in South-Western Nigeria. International Journal of Research and Review. 2021; 8(11): 423-430. DOI: https://doi.org/10. 52403/ijrr.20211154 